Terbit online pada laman web jurnal : http://e-journal.sastra-unes.com/index.php/JIPS

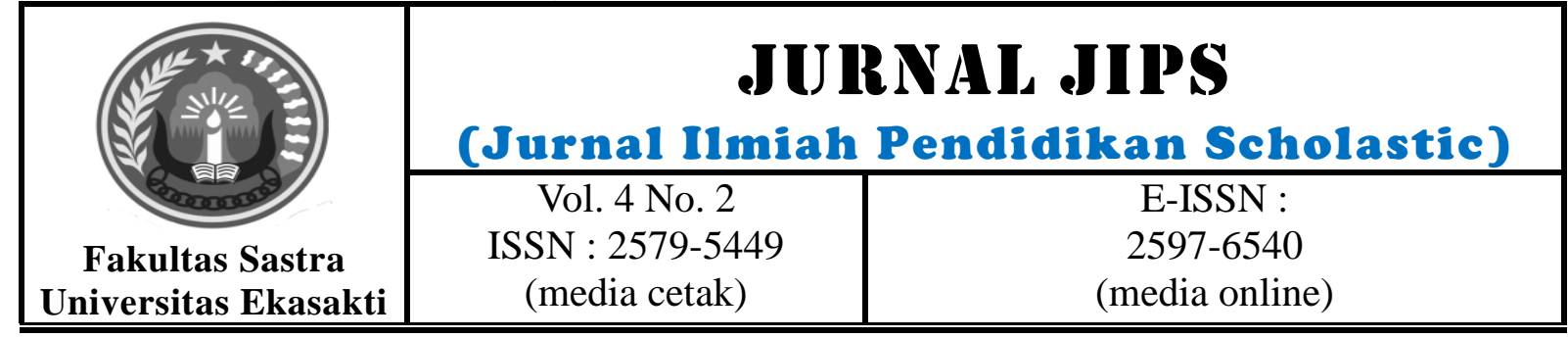

\title{
PENGOLAHAN DATA PEGAWAI PADA KANTOR SATUAN POLISI PAMONG PRAJA KOTA PAYAKUMBUH MENGGUNAKAN APLIKASI BERBASIS WEB
}

\author{
Sophan Sophian \\ STIE KBP Padang \\ ophancpu@gmail.com
}

\begin{abstract}
Abstrak
Pada masa sekarang ini tidak ada satu instansi pemerintahan yang tidak menggunakan komputer untuk melakukan kegiatan pengolahan data, tidak terkecuali Satuan Polisi Pamong Praja yang lebih kita kenal dengan Satpol PP. Pengolahan data pegawai pada Kantor Satuan Polisi Pamong Praja Payakumbuh sudah menggunakan komputer, namun belum mengunakan sebuah sistem yang dapat membantu dalam penyusunan laporan yang cepat dan efisien.Untuk itu dibangun sebuah sistem informasi yang berbasis WEB untuk pengolahan dan pembuatan laporan pegawai, laporan kenaikan pangkat pegawai,dan juga laporan kenaikan gaji berkala pegawai. Sehingga informasi dapat disajikan dengan cepat dan tepat.Kelebihan dari sistem yang diusulkan ini adalah dalam pencatatan dan disimpan dalam sebuah database sehingga memudahkan dalam pembuatan laporan.
\end{abstract}

Keywords: Sistem, Informasi, Pengolahan, Data Pegawai

(C) 2020Jurnal JIPS

\section{INTRODUCTION}

Berkembang pesatnya Ilmu Pengetahuan dan Teknologi yang dirasakan dan yang dipelajari dalam dunia pendidikan sekarang ini menjadi momentum dan pemicu bagi perkembangan instansi, seperti dibidang pendidikan maupun dunia usaha.

Pada masa pandemi seperti sekarang ini maka banyak yang beubah, terutama kebiasaan dalam bekerja. Semua telah menggunakan teknologi. Seperti halnya Kantor Satuan Polisi Pamong Praja Kota Payakumbuh penggunaan teknologi komputer telah mendorong kemajuan terutama dalam hal pengelolahan data.

Dalam kegiatan operasionalnya pada Kantor Satuan Polisi Pamong Praja mengolah data pegawai sudah menggunakan komputer, namun tidak didukung oleh program aplikasi data pegawai, data masih diarsip dalam bentuk lembaran kertas yang tercetak dan arsip disimpan di lemari arsip. Untuk mencetak laporan, di butuhkan waktu dan tenaga yang ekstra untuk menyatukan dan mencari lembaran-lembaran arsip. Selain itu data yang sama diinput berulangulang sehingga waktu dan tenaga tidak digunakan secara efisien.

Dari data pegawai penulis juga menemukan permasalahan lain yang di keluhkan saat pengolahan data gaji berkala karyawan, masih menggunakan sistem yang manual yang masih dibuat pada buku besar sehingga membuat karyawan menjadi kesulitan dalam penginputan data gaji karyawan, apabila ada karyawan baru masuk lagi maka bagian bendahara gaji harus mencatat kembali dengan nomor nip, kapan jatuh tempo gaji berkala dan juga biodata lengkap yang baru. Dan juga masalahnya dalam

Jurnal JIPS (Jurnal Ilmiah Pendidikan Scholastic) Vol. 4No. 2 (2019) ISSN : 2579-5449

This work is licensed under a Creative Commons Attribution-NonCommercial 4.0 International License. 
pencatatan daftar nama pegawai yang cuti dan lembur masih meginputkan dengan excel, sehingga sering terjadi kesalahan.

Proses tersebut akan mempersulit bagian bendahara gaji dalam pembuatan laporan karena harus mencari lagi dimana karyawan yang telah terdaftar pada hari,bulan,tahun dan tanggal gaji berkala karyawan.Kemudian sering juga terjadi keraguan kapan waktu gaji berkala karyawan dalam laporan keuangan karena setiap pembutan laporan bagian bendahara gaji harus mengecek satu-persatu data karyawan yang jatuh tempo waktu gaji berkalanya.Hal ini akan menyebabkan sering terjadi kesalahan laporan gaji berkala yang di terima oleh Kasat, dan juga di kantor ini sering terjadi kesalahan dalam kenaikan pangkat pegawai karna sistem input data masih memakai excel. Oleh karna itu Sistem yang sedang berjalan pada pada Kantor Satuan Polisi Pamong Praja ini belum bisa menjamin informasi dari laporannya dan juga saat mengumpulkan data, sering terjadi keterlambatan dalam penyajian data pegawai.

Keterkaitan manusia dan teknologi komputer sangatlah dibutuhkan untuk membangun sebuah sistem informasi. Penulis tertarik untuk membangun sebuah sistem informasi yang berhubungan dengan kepegawaian dalam hal ini sebuah Sistem Informasi Data Pegawai pada suatu instansi untuk dapat mempermudah instansi tersebut dalam melakukan aktivitas kerja.

\section{KAJIAN LITERATUR}

Menurut Tata Sutabri didalam buku yang berjudul "Konsep Sistem Informasi" yang ditulis olehTata Sutabri(2012:46) mendefinisikan, "Sistem Informasi sebagai suatu sistem di dalam suatu organisasi yang mempertemukan kebutuhan pengolahan transaksi harian yang mendukung fungsi operasi organisasi yang bersifat manajerial dengan kegiatan strategi dari suatu organisasi untuk dapat menyediakan kepada pihak luar tertentu dengan laporan laporan yang diperlukan oleh pihak luar tertentu".

Menurut Sutanta sendiri, mengenai Sistem Informasi menyebutkan didalam buku yang berjudul "Basis Data" yang ditulis oleh Edhy Sutanto (2011:16) bahwa:"Dalam arti yang luas sistem informasi dapat dipahami sebagai sekumpulan subsistem yang saling berhubungan, berkumpul bersama-sama dan membentuk satu kesatuan, saling berinteraksi dan bekerja sama antara bagian satu dengan yang lainnya dengan cara-cara tertentuk untuk melakukan fungsi pengolahan data, menerima masukan (input) berupa data, kemudian mengolahnya (processing) dan menghasilkan keluaran (output) berupa informasi sebagai dasar bagi pengambilan keputusan yang berguna dan mempunyai nilai nyata yang dapat dirasakan akibatnya baik pada saat itu juga maupun di masa mendatang, mendukung kegiatan operasiona, manajerial, dan strategis organisasi, dengan memanfaatkan berbagai sumber daya yang ada dan tersedia bagi fungsi tersebut guna mencapai tujuan."
1. Sistem Pegawai Informasi Pengolahan
Data

Sistem Informasi pengolahan data pegawai pada Kantor Satuan Polisi Pamong Praja Kota Payakumbuh Dinas menggunakan program aplikasi yang dapat mengolah data pegawai. Sistem informasi pengolahan data pegawai ini dikelola langsung oleh bagian Fungisional administrasi yang menghasilkan laporan berupa laporan data pegawai,laporan kenaikan pangkat, laporan gaji berkala pegawai.

Aplikasi pengolahan data pegawai ini membutuhkan entri data pegawai,entri data cuti,entri data lembur dan entri data pangkat terakhir dan gaji berkala terkhir, yang selanjutnya akan disimpan pada database. Pada sistem pengolahan data pegawai dengan menggunakan aplikasi sistem informasi, menghasilkan laporan-laporan yang efisien, akurat, tepat waktu dan bermanfaat.

2. Data Pegawai, Cuti, Lembur, Daftar Urut Kepangkatan (DUK), Kenaikan Pangkat Pegawai dan Kenaikan Gaji Berkala Pegawai

\section{a. Pengertian Data}

Data secara konseptual adalah deskripsi tentang benda, kejadian, aktivitas,dan transaksi yang tidak mempunyai makna atau berpengaruh secara langsung kepada pemakai.

Menurut Vardiansyah, Dani dalam buku Filsafat Ilmu Komunikasi (2008:3) Data merupakan atas kumpulan fakta tertentu sehingga

Jurnal JIPS (Jurnal Ilmiah Pendidikan Scholastic) Vol. 4No. 2 (2019) ISSN : 2579-5449 
menghasilkan suatu kesimpulan dalam menarik suatu keputusan.

\section{b. Pengertian Pegawai}

Di dalam masyarakat yang selalu berkembang, manusia senantiasa mempunyai kedudukan yang masih penting, meskipun negara Indonesia menuju kepada masyarakat yang berorientasi kerja, yang memandang kerja adalah sesuatu yang mulia, tidaklah berarti mengabaikan manusia yang melaksanakan kerja tersebut. Demikian juga halnya dalam suatu organisasi ,unsur manusia sangat menentukan sekali karena berjalan tidaknya suatu organisasi kearah pencapaian tujuan yang ditentukan tergantung kepada kemampuan manusia untuk menggerakkan organisasi kearah yang telah ditetapkan. Manusia yang terlibat dalam organisasi ini disebut juga pegawai.
Menurut
A.W.Widjaja
(2007
:113)

Pegawai adalah orang-orang yang dikerjakan dalam suatu badan tertentu, baik di lembaga lembaga pemerintah maupun dalam badan badan usaha.

Menurut Soedaryono (2010:7) Pegawai adalah golongan masyarakat, yang melakukan penghidupannya dengan bekerja dalam kesatuan organisasi, baik kesatuan pemerintah,maupun keasatuan kerja swasta.

Pegawai merupakan kelompok atau anggota di suatu organisasi dan melaksanakan pekerjaan yang telah di tetapkan dan merupakan pekerjaan yang melaksanakan kegiatan-kegiatan rutin untuk mencapai hasil kerja yang diinginkan sesuai dengan apa yang akan dicapai.

\section{c. Pengertian Cuti}

Berdasarkan Peraturan Pemerintah No.24 Tahun 1967 berisikan tentang Cuti Pegawai Negeri Sipil, selanjutnya disingkat dengan cuti adalah keaadan tidak masuk kerja yang diizinkan dalam jangka waktu tertentu.

\section{d. Pengertian Lembur (Overtime)}

Menurut Lestari (2009), overtime atau jam lembur merupakan waktu bekerja per minggu yang melebihi standar jam kerja di suatu daerah tertentu.

Di Indonesia, ketentuan kerja lembur di atur oleh Menteri Tenaga Kerja dengan dikeluarkannya SK Menteri Tenaga Kerja No.58/M/BM/BK/1992 pasal 2 dan 3, yang menyebutkan bahwa kerja lembur merupakan waktu dimana seorang pekerja bekerja melebihi dari jadwal waktu yang berlaku, yaitu 7 (tujuh) jam sehari dan 40 (empat puluh) jam seminggu.

\section{e. Pengertian DUK (Daftar Urut Kepangkatan ) \\ DUK (Daftar Urut Kepangkatan) adalah} suatu daftar yang memuat nama pegawai negeri sipil dari satuan organisasi negara yang disusun menuru tingkat kepangkatan. Daftar ini dibuat pada akhir bulan Desember dan berlaku untuk tahun berikutnya.

Tujuan Dibuatnya DUK yaitu untuk lebih menjamin objektifitas dalam pembinaan pegawai negeri sipil berdasarkan sistem karier dan sistem prestasi kerja, DUK digunakan sebagai salah satu pertimbangan objektif dalam melaksanakan pembinaan karier pegawai.

f. Pengertian Kenaikan Pangkat Pegawai Negeri Sipil

Dalam rangka usaha melaksanakan pembinaan pegawai negeri sipil atas dasar system karier dan system prestasi kerja maka perlu ditetapkan ketentuan tentang pengangkatan dalam pangkat pegawai negeri sipil .

Pangkat adalah kedudukan yang menunjukkan tingkat seseorang pegawai negeri sipil dalam rangkaian susunan kepegawaian dan digunakan sebagai dasar penggajian, oleh karena itu setiap pegawai negeri sipil diangkat dalam pangkat tertentu. Kenaikan pangkat adalah penghargaan yang diberikan atas pengabdian pegawai negeri sipil yang yang bersangkutan terhadap negara, selain pada itu kenaikan pangkat juga dimaksudkan sebagai dorongan kepada pegawai negeri sipil untuklebih meningkatkan pengabdiannya.

\section{g. Kenaikan Gaji Berkala Pegawai}

Dasar Hukum,Peraturan Pemerintah Nomor 7 Tahun 1977 tentang Peraturan Gaji PNS sebagaimana telah diubah dengan Peraturan Pemerintah Nomor 15 Tahun 2012. Kenaikan Gaji Berkala adalah kenaikan gaji yang diberikan kepada PNS yang telah mencapai masa kerja golongan yang ditentukan untuk kenaikan gaji berkala yaitu setiap 2 (dua) tahun sekali dan apabila telah memenuhi persyaratan berdasarkan peraturan perundang - undangan yang berlaku.Kenaikan Gaji Berkala untuk pertama kali bagi seorang PNS yang diangkat dalam golongan I, II, III diberikan setelah mempunyai masa kerja 2 (dua) tahun sejak diangkat menjadi calon PNS dan selanjutnya 2 (dua) tahun sekali,

Jurnal JIPS (Jurnal Ilmiah Pendidikan Scholastic) Vol. 4No. 2 (2019) ISSN : 2579-5449 
kecuali untuk PNS yang pertama kali diangkat dalam golongan II/a diberikan kenaikan gaji berkala pertama kali setelah mempunyai masa kerja 1 (satu) tahun dan selanjutnya setiap 2 (dua) tahun sekali.

(Sumber: Arsip Kantor

SatuanPolisiPamongPraja Kota Payakumbuh. 2013)

3. MySQL

Menurut A.M. Hirin dan Virgi (2011:27), bahwa:

"MySQL adalah salah satu perangkat lunak sistem manajemen basis data (database) SQL atau sering disebut dengan DBMS (Database Management System)".

Berbeda dengan basis data konvensional seperti .dat, .dbf, .mdb, MySQL memiliki kelebihan yaitu bersifat multithread dan multiuser serta mendukung sistem jaringan. MySQL didisribusikan secara gratis dibawah lisensi GNU GeneralPublicLicense (GPL), namun ada juga versi komersial bagi kalangan tertentu yang menginginkannya.

\section{Perancangan Sistem}

Desain sistem adalah sebuah teknik pemecahan masalah yang sling melengkapi yang merangkai kembali bagian-bagian komponen menjadi sistem yang lengkap, harapannya untuk sebuah sistem yang diperbaiki.

\section{Sistem}

5. Alat Bantu Perancangan

1. Aliran Sistem Informasi (ASI)

\section{RESEARCH METHOD}

\section{PROSES PERANCANGAN SISTEM 1. Desain Global}

Perancangan global atau desain konseptual (conceptual design) atau disebut juga dengan desain logika (logical design), yaitu perancangan prosedur sistematika, logika, atau algoritma sistem secara konseptual yang berfungsi untuk membenahi sistem yang sedang berjalan. Dalam perancang global ini, akan menguraikan bagan arsitektur sistem yang diusulkan berupa, HIPO (Hierarchy Plus Input Process Output), CD (Contex Diagram),DFD (Data Flow Diagram), ERD (Entity Relationship Diagram).
Aliran sistem informasi sangat berguna untuk mengetahui permasalahan yang ada pada suatu sistem. Dari sini dapat diketahui apakah sistem informasi tersebut masih layak dipakai atau tidak, masih manual atau komputerisasi.

\section{Hierarchy Input Proces Output(HIPO)}

HIPO merupakan teknik untuk mendokumentasikan pengembangan suatu sistem yang dikembangkan oleh IBM. HIPO dapat digunakan untuk memenuhi kebutuhan beberapa pengguna untuk kepentingan berbeda-beda.

\section{Context Diagram (CD)}

Context Diagram (CD) adalah diagram yang terdiri dari suatu proses dan menggambarkan ruang lingkup suatu sistem. Diagram konteks merupakan level tertinggi dariData Flow Diagram (DFD) yang menggambarkan seluruh input ke sistem atau output dari sistem.

\section{Data Flow Diagram (DFD)}

DFD merupakan gambaran sistem secara logika yang tidak tergantung pada perangkat keras, lunak, struktur data dan organisasi file. Keuntungan dari DFD adalah untuk memudahkan pemakai yang kurang menguasai bidang komputer untuk mengerti system yang akan dikerjakan atau dikembangkan.

\section{a. Hierarchy Plus Input Process Output (HIPO)}

Jurnal JIPS (Jurnal Ilmiah Pendidikan Scholastic) Vol. 4No. 2 (2019) ISSN : 2579-5449 
HIPO merupakan alat dokumentasi program yang berdasarkan fungsinya untuk meningkatkan efesiensi usaha pengolahan data program. Dokumen ini dilaksanakan dengan mempercepat lokasi dalam kode pada fungsi program yang akan dimodifikasi.

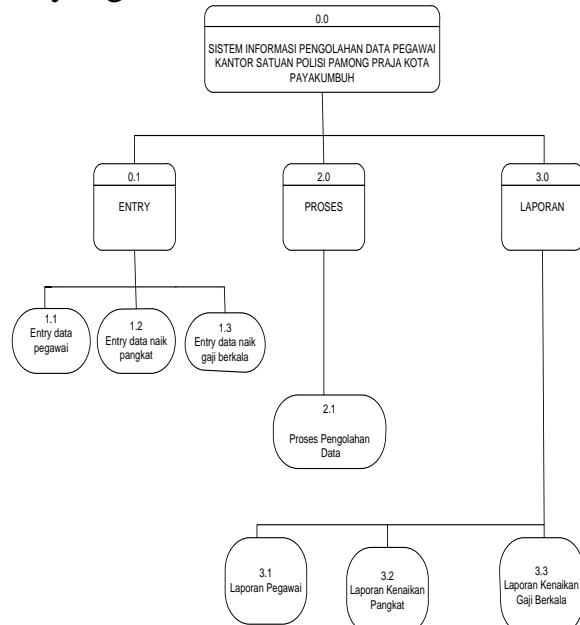
Gambar 1 HIPO (Hierarchy Plus Input
Process Output)

\section{b. Context Diagram ( CD)}

Context Diagram (CD) merupakan bentuk umum mengenai suatu sistem yang terdapat didalam suatu organisasi yang memperlihatkan batasan (boundary) sistem yaitu interaksi antara eksternal entity dengan suatu sistem, dan informasi secara umum mengalir diantara entity dan sistem. Context Diagram juga merupakan alat bantu yang digunakan dalam menganalisa sistem yang akan dikembangkan.

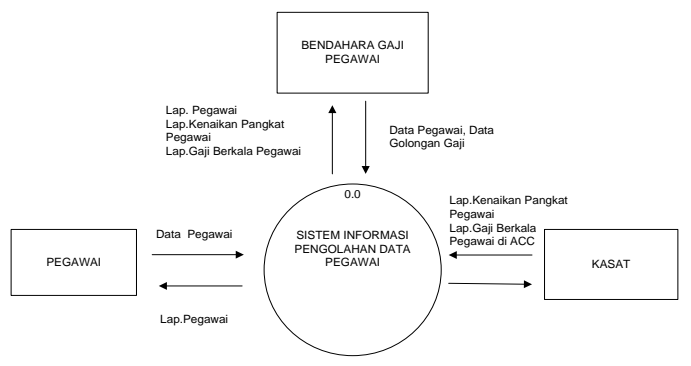

Data Flow Diagram (DFD) merupakan alat pengembangan sistem yang akan mengambarkan arus data dalam sistem yang dirancang. Pengembangan sistem dimulai dari bentuk Data Flow Diagram (DFD).

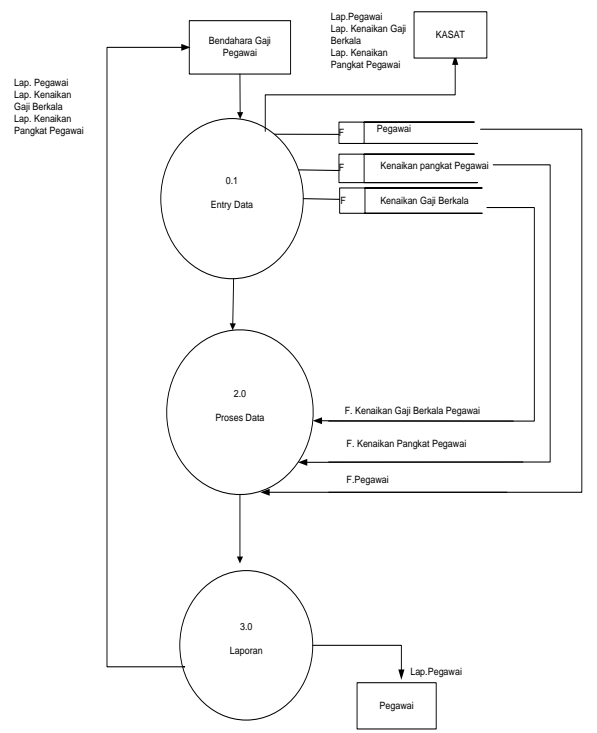

Gambar 3 Data Flow Diagram (DFD) (ERD)

\section{d. Entity Relationship Diagram}

Entity Relationship Diagram (ERD) merupakan suatu dokumentasi data dalam mengidentifikasi entity data dan memperlihatkan hubungan yang ada dalam entity tersebut.

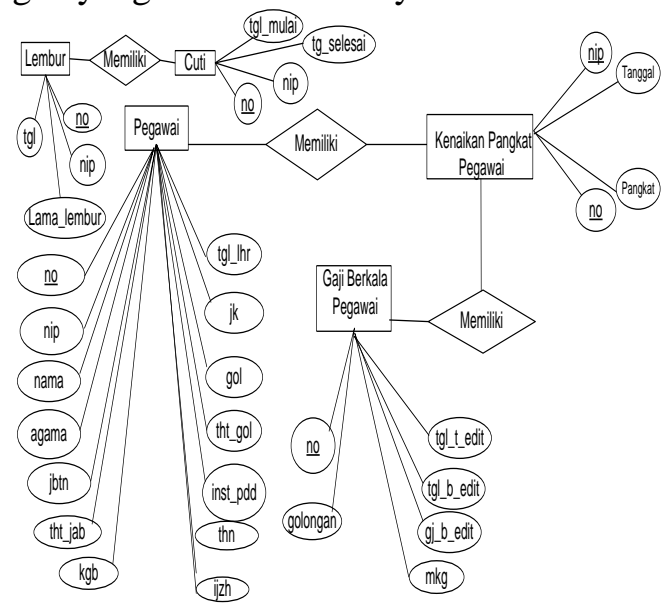

Gambar 4 Entity Relationship Diagram (ERD)

\section{Gambar 2 Context Diagram}

\section{c. DFD ( Data Flow Diagram)}

Jurnal JIPS (Jurnal Ilmiah Pendidikan Scholastic) Vol. 4No. 2 (2019) ISSN : 2579-5449 


\section{RESULTS AND DISCUSSION}

Tahap implemetasi merupakan tahap dalam menggambarkan sistem, yaitu meletakan sistem supaya siap dioperasikan. Implementasi berguna untuk memudahkan penerapan sistem

\section{CONCLUSION}

Setelah mengadakan analisa terhadap masalah utama sistem informasi pengolahan data pegawai pada Kantor Satuan Polisi Pamong Praja Kota Payakumbuh. Dan berdasarkan bab-bab sebelumnya dapat diambil kesimpulan sehubungan dengan sistem informasi pengolahan data pegawai pada Kantor Satuan Polisi Pamong Praja Kota Payakumbuh yaitu sebagai berikut :

1. Dengan penerapan sistem yang baru pada Kantor Satuan Polisi Pamong Praja Kota Payakumbuh, laporan data pegawai yang dihasilkan menjadi lebih efisien dan cepat yang di siapkan agar pengentrian data sampai pada penyajian informasi sesuai dengan prosedur yang telah direncanakan.

2. Untuk mempermudah dalam penyimpanan data pegawai, dan mempermudah untuk melihat kenaikan pangkat pegawai, dan melihat kapan jatuh tempo gaji berkala pegawai maka dibangun Pengolahan Data Pegawai Pada Kantor Satuan Polisi Pamong Praja Kota Payakumbuh Manggunakan Aplikasi Berbasis WEB.

Pengolahan Data Pegawai Pada Kantor Satuan Polisi Pamong Praja Kota Payakumbuh Manggunakan Aplikasi Berbasis WEB akan lebih cepat dalam proses pembuatan laporan. 


\section{Bibliography}

[1]Rusdiana, Irfan Moch. (2014).Sistem informasi Manajemen. Bandung: Penerbit CV. Pustaka Setia.

[2]HM Jogiyanto. (2009). Sistem Teknologi Informasi: PendekatanTerintegrasi: KonsepDasar, Teknologi, Aplikasi, Pengembangan dan Pengelolaan. Yogyakarta: Penerbit CV. Andi Offset.

[3]Sutabri Tata. (2012).Analisis Sistem Informasi. Yogyakarta: Penerbit CV. Andi Offset.

[4]Sutabri Tata. (2013).Konsep Sistem Informasi. Yogyakarta: Penerbit CV. Andi Offset.

[5]Sutanta Edhy.(2011).Basis Data. Yogyakarta: Penerbit CV. Andi Offset.

[6]Indah Novita Sari. (2015). Sistem Informasi (Sisfo) Pengolahan Data Pegawai Pada
Kantor Satuan Polisi Pamong Praja Kota Payakumbuh Menggunakan Php Myadmin Berbasis Web. Skripsi, Tidak Diterbitkan, STMIK Indonesia Padang.

[7]Arsip Kantor Satuan Polisi Pamong Praja Kota Payakumbuh. 2013

[8]Fatta, Hanif Al.(2007). Analisis dan Perancangan Sistem Informasi. Jakarta:Andi Offset.

[9]Supardi yuniar (2010).Semua Bisa Jadi Programmer Visual FoxPro 9.0.Jakarta: Penerbit PT. Elex Media Komputindo.

[10]Al-Bahra bin Ladjamudin (2013).Analisa dan desain system informasi. Yogyakarta: Penerbit Graha Ilmu.

[11]Kusrini. (2007). Strategi Perancangan dan Pengelolaan Basis Data. Yogyakarta : Andi Offset. 